\title{
Physiology and behaviour of marine Thioploca
}

Signe Høgslund ${ }^{1}$, Niels Peter Revsbech ${ }^{1}$, J Gijs Kuenen ${ }^{2}$, Bo Barker Jørgensen ${ }^{3,4}$, Victor Ariel Gallardo ${ }^{5}$, Jack van de Vossenberg ${ }^{6}$, Jeppe Lund Nielsen ${ }^{7}$, Lars Holmkvist ${ }^{3}$, Esther T Arning ${ }^{8}$ and Lars Peter Nielsen ${ }^{1}$

${ }^{1}$ Department of Biological Sciences, University of Aarhus, Aarhus, Denmark; ${ }^{2}$ Department of Biotechnology, Delft University of Technology, Delft, The Netherlands; ${ }^{3}$ Max Planck Institute for Marine Microbiology, Bremen, Germany; ${ }^{4}$ Center for Geomicrobiologi, Department of Biological Sciences, University of Aarhus, Aarhus, Denmark; ${ }^{5}$ Department of Oceanography, University of Concepción, Concepción, Chile; ${ }^{6}$ Department of Microbiology/IWWR, Radboud University Nijmegen, Nijmegen, The Netherlands; ${ }^{7}$ Department of Biotechnology, Chemistry and Environmental Engineering, Aalborg University, Aalborg, Denmark and ${ }^{8}$ MARUM-Center for Marine Environmental Sciences, University of Bremen, Bremen, Germany

\begin{abstract}
Among prokaryotes, the large vacuolated marine sulphur bacteria are unique in their ability to store, transport and metabolize significant quantities of sulphur, nitrogen, phosphorus and carbon compounds. In this study, unresolved questions of metabolism, storage management and behaviour were addressed in laboratory experiments with Thioploca species collected on the continental shelf off Chile. The Thioploca cells had an aerobic metabolism with a potential oxygen uptake rate of $1760 \mu \mathrm{mol} \mathrm{O} \mathrm{O}_{2}$ per $\mathrm{dm}^{3}$ biovolume per $\mathrm{h}$, equivalent to $4.4 \mathrm{nmol} \mathrm{O}_{2}$ per min per $\mathrm{mg}$ protein. When high ambient sulphide concentrations $(\sim 200 \mu \mathrm{M})$ were present, a sulphide uptake of $6220 \pm 2230 \mu \mathrm{mol} \mathrm{H}_{2} \mathrm{~S}$ per $\mathrm{dm}^{3}$ per $\mathrm{h}$, (mean \pm s.e.m., $n=4$ ) was measured. This sulphide uptake rate was six times higher than the oxidation rate of elemental sulphur by oxygen or nitrate, thus indicating a rapid sulphur accumulation by Thioploca. Thioploca reduce nitrate to ammonium and we found that dinitrogen was not produced, neither through denitrification nor through anammox activity. Unexpectedly, polyphosphate storage was not detectable by microautoradiography in physiological assays or by staining and microscopy. Carbon dioxide fixation increased when nitrate and nitrite were externally available and when organic carbon was added to incubations. Sulphide addition did not increase carbon dioxide fixation, indicating that Thioploca use excess of sulphide to rapidly accumulate sulphur rather than to accelerate growth. This is interpreted as an adaptation to infrequent high sulphate reduction rates in the seabed. The physiology and behaviour of Thioploca are summarized and the adaptations to an environment, dominated by infrequent oxygen availability and periods of high sulphide abundance, are discussed.
\end{abstract}

The ISME Journal (2009) 3, 647-657; doi:10.1038/ismej.2009.17; published online 5 March 2009

Subject Category: Microbial population and community ecology

Keywords: nitrate metabolism; oxygen uptake; phosphate; sulphide uptake; Thioploca

\section{Introduction}

Extensive areas of the continental shelf along the coast of Peru and Chile (Gallardo, 1963, 1977a, b; Schulz et al., 2000) and also other oxygen minimum zones (OMZs; Schmaljohann et al., 2001; Bernhard and Buck, 2004) are inhabited by so-called 'macrobacteria' (Gallardo and Espinoza, 2007a, b). Among those, we find dense populations of giant filamentous sulphide-oxidizing bacteria belonging to the

Correspondence: LP Nielsen, Department of Biological Sciences, Microbiology, University of Aarhus, bld. 1540, DK-8000 Aarhus C, Denmark.

E-mail: biolpn@biology.au.dk

Received 11 December 2008; revised 9 February 2009; accepted 9 February 2009; published online 5 March 2009 genus Thioploca. The marine Thioploca community is dominated by two species, T. chileae and T. araucae with average trichome (filament) diameters of 16 and $32 \mu \mathrm{m}$, respectively (Maier and Gallardo, 1984a). The bacterial trichomes generally live in bundles surrounded by a common sheath, which can be several centimetres long (Schulz et al., 2000), but occasionally they may also be found as freeliving trichomes and thereby resemble Beggiatoa (VA Gallardo, personal observation). Thioploca accumulate nitrate in concentrations up to $0.5 \mathrm{M}$ (Fossing et al., 1995). The trichomes take up nitrate from seawater at the sediment surface and transport it in intracellular vacuoles down into the sediment, where it is used to oxidize sulphide to intracellular sulphur (Huettel et al., 1996). The simultaneous 
storage of nitrate and sulphur enables the trichomes to sustain a continuous energy metabolism as they migrate up and down in an environment where their electron donor and acceptor do not coexist.

Thioploca show close phylogenetic affiliation to marine Beggiatoa and Thiomargarita (Teske et al., 1996; Jørgensen et al., 2005; Ahmad et al., 2006). Several studies have shown that all these giant sulphur bacteria employ similar metabolic strategies. These include nitrate and sulphur accumulation, mixotrophic assimilation of $\mathrm{CO}_{2}$ and organic substrates such as acetate, and the ability to perform dissimilatory nitrate reduction to ammonium (DNRA; Fossing et al., 1995; McHatton et al., 1996; Otte et al., 1999; Schulz et al.,1999; Sayama et al., 2005). Recent genomic studies of Beggiatoa and physiological studies of Thiomargarita (Schulz and de Beer 2002; Schulz and Schulz 2005; Mussman et al., 2007) indicate that the giant sulphur bacteria have diverse pathways of energy metabolism, which includes both DNRA and denitrification, oxygen respiration and an auxiliary energy reservoir of polyphosphate. The question arises whether these properties also apply to Thioploca.

Thiomargarita accumulate and reduce nitrate and also have an aerobic metabolism (Schulz and de Beer, 2002). Aerobic sulphide oxidation is both documented experimentally (Jørgensen and Revsbech, 1983; Nelson et al., 1986b; Sayama et al., 2005) and indicated genetically (Mussmann et al., 2007) in Beggiatoa. Similar to Beggiatoa, Thioploca shows phobic response to oxygen concentrations exceeding 10-20 $\mu \mathrm{M}$ (Huettel et al., 1996). Low oxygen concentrations do not inhibit carbon dioxide assimilation (Otte et al., 1999). However, oxygen uptake by Thioploca has not been studied.

Sulphide oxidation by the large marine sulphur bacteria affects mineral cycling in many organic-rich surface sediments (for example, Ferdelman et al., 1997; Mussmann et al., 2003; de Beer et al., 2006; Preisler et al., 2007). Only one study has addressed the biomass-specific sulphide oxidation rate of Thioploca (Otte et al., 1999). By living in bundles, Thioploca are even more exposed to diffusion limitation than Beggiatoa trichomes (Schulz and Jørgensen, 2001). The extent to which this affects sulphide uptake rates, remains to be determined by direct measurements of the biomass-specific sulphide uptake.

It has recently been suggested that giant sulphur bacteria interact with phosphorus cycling in sediments where they are found in high densities (Schulz and Schulz, 2005; Arning et al., 2008). Thiomargarita have the ability to store polyphosphate as an energy reserve. The alternating storage and release of phosphate appears to enhance the formation of large phosphorite deposits in the sea bead in the same coastal OMZs where the large sulphur bacteria predominate (Schulz and Schulz 2005). The genetic potential for such a metabolism is also indicated in Beggiatoa (Mussmann et al., 2007).
If Thioploca would have similar properties, their massive presence in the Peruvian and Chilean sediments might impact on phosphate cycling here. However, experimental evidence of phosphate accumulation and subsequent release is not yet available for Thioploca.

DNRA is well documented in both Beggiatoa and Thioploca (Otte et al., 1999; Sayama, 2001; Sayama et al., 2005; Preisler et al., 2007). In addition to this, it seems that at least some marine and freshwater Beggiatoa have the capacity to denitrify (Sweerts et al., 1990; Mussmann et al., 2007). A study of nitrogen metabolism in Thioploca left the question about denitrification in this genus open (Otte et al., 1999). Thioploca sheaths are a potentially favourable niche for the anammox bacteria, because both nitrite and ammonium could be scavenged from DNRA in Thioploca (Prokopenko et al., 2006). This possible association needs molecular and biochemical evidence, and the potential of Thioploca to denitrify or perform the anammox reaction requires further testing.

In this study, we wanted to clarify the unresolved aspects of Thioploca physiology described above by studying oxygen respiration, sulphide oxidation, polyphosphate storage, denitrification and anammox activity associated with Thioploca. We also examine substrate uptake in cleaned bundles of Thioploca, analyse carbon incorporation by quantitative microautoradiography and follow trichome movements and behaviour to understand the Thioploca way of life.

\section{Materials and methods}

Sampling

Sediment cores $(9 \mathrm{~cm}$ inner diameter) containing Thioploca were collected with a multiple corer during January 2006 about $30 \mathrm{~km}$ northwest of Concepción, Chile, at Station 7 (36 m water depth, $36^{\circ} 36^{\prime} \mathrm{S}, 73^{\circ} 00^{\prime} \mathrm{W}$ ) and Station 18 (93 m water depth, $\left.36^{\circ} 31^{\prime} \mathrm{S}, 73^{\circ} 08^{\prime} \mathrm{W}\right)$. Thioploca used in physiological assays were collected with a GOMEX Box corer (Gilbert Rowe, Texas A\&M University, Galveston, TX, USA). All samples were kept at in situ temperature $\left(11^{\circ} \mathrm{C}\right)$ until processing at the Dichato Marine Biological Station of the University of Concepción. Samples were stored with $100 \mu \mathrm{M}$ nitrate in the overlying water phase and were processed within 8 days of sampling.

\section{Microgradients}

Gradients of oxygen, nitrous oxide, sulphide and $\mathrm{pH}$ were analysed around bundles of Thioploca araucae with microsensors. A schematic illustration of the experimental setup is shown in Figure 1. The applied oxygen, nitrous oxide, sulphide and $\mathrm{pH}$ microsensors (Revsbech and Jørgensen, 1986; Revsbech, 1989; Kühl et al., 1998; Andersen et al., 


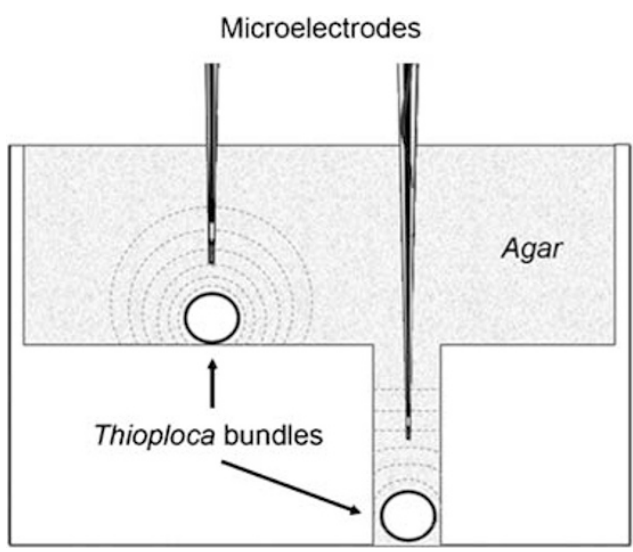

Figure 1 Cross-section of setup with bundle placed in the groove of the glass aquarium. Dotted lines represent concentration isopleths. Not drawn to scale.

2001) had detection limits of $<0.5 \mu \mathrm{M},<1 \mu \mathrm{M},<1 \mu \mathrm{M}$ and $<0.05 \mathrm{pH}$ units, respectively. The Thioploca bundles were placed either in a $2.5 \mathrm{~mm}$ deep and $0.57 \mathrm{~mm}$ wide groove (for oxygen, nitrous oxide and $\mathrm{pH}$ measurements) or on a flat surface. The use of a groove resulted in steeper gradients and enabled more accurate diffusion flux calculations. However, excessively high sulphide concentrations would have been necessary to saturate the uptake, and these experiments were, therefore, conducted while the trichomes were lying on a flat glass surface and supplied with sulphide by half-cylindrical diffusion. For oxygen measurements one bundle was placed in the groove. For nitrous oxide determinations five bundles with diameters of 0.4-0.5 $\mathrm{mm}$ were aggregated to lower the detection limit. To examine possible interference from attached bacteria, the sheaths were carefully pealed off in one end of the bundles, making measurements on free trichomes possible. Control measurements of substrate uptake were also performed on removed sheath material. Bundles were covered by a $1-1.6 \mathrm{~cm}$ thick layer of agar-stabilized seawater medium, which prevented advection and allowed for analysis at defined sulphide or low oxygen concentrations.

The agar cover for oxygen uptake experiments was made from in situ bottom seawater with $10 \%$ of atmospheric oxygen saturation obtained by nitrogen bubbling. It was subsequently heated to $45^{\circ} \mathrm{C}$ in serum bottles with $10 \%$ atmospheric oxygen tension in the headspace before $10 \%$ (liquid vol/vol) $2 \%$ agar in $3.5 \% \mathrm{NaCl}$ solution was injected. Equilibrium between headspace and agar was approached by leaving the bottles in a horizontal position at $11^{\circ} \mathrm{C}$ until the next day. The medium for nitrous oxide and sulphide measurements was made in a similar manner but without oxygen. Acetylene blocks the last step in the denitrification pathway, and denitrification can, therefore, be quantified by measuring nitrous oxide production (Smith et al., 1978). For the nitrous oxide detection experiment, nitrate was added to a concentration of $250 \mu \mathrm{M}$ and a headspace of $20 \%$ acetylene and $80 \%$ argon was applied in the serum bottles. Medium for sulphide measurements was buffered with $10 \mathrm{mM}$ morpholinoethanesulphonic acid buffer. Sulphide was added to final concentrations of 100 and $200 \mu \mathrm{M}$. The $\mathrm{pH}$ in the final solutions varied from 7.00 in the $100 \mu \mathrm{M}$ solution to 7.07 in the $200 \mu \mathrm{M}$ solution. All manipulations of Thioploca and measurements were conducted at $11^{\circ} \mathrm{C}$.

For bundles placed in the groove, calculation of diffusion fluxes per length of bundle $(J)$ from the concentration $(C)$ change with depth $(x)$ were performed by Fick's first law of diffusion:

$$
J=w D \delta C / \delta x
$$

where $D$ is the diffusion coefficient and $w$ is the width of the groove.

When bundles were placed at the flat glass surface, the flux could be calculated from the concentration gradient $\delta C / \delta x$ measured at some distance from the periphery of the bundle anticipating a half cylindrical diffusion geometry (one half cylinder being blocked by the glass; Figure 1). Cylindrical diffusion fluxes can be calculated from:

$$
J=2 \pi R D \delta C / \delta x
$$

where $R$ is the radial distance from the centre of the bundle to the point of determination of $\delta C / \delta x$ (Crank, 1983). The diffusion coefficient for oxygen in seawater at $11^{\circ} \mathrm{C}$ is $1.51 \times 10^{-5} \mathrm{~cm}^{2} \mathrm{~s}^{-1}$ (tables at www.unisense.com), and the diffusion coefficient for sulphide was estimated to be $1.11 \times 10^{-5} \mathrm{~cm}^{2} \mathrm{~s}^{-1}$ (Nelson et al., 1986a). The sum of $\mathrm{H}_{2} \mathrm{~S}$ and $\mathrm{HS}^{-}\left(\mathrm{S}_{\mathrm{tot}}\right)$ was calculated from $\mathrm{pH}$ and sulphide data (Hershey et al., 1988). From fluxes and bundle diameters, metabolic rates could be expressed in units of biovolume. In converting these rates to activity per biomass protein a conversion factor of $7 \mathrm{mg}$ protein per $\mathrm{cm}^{3}$ was used based on our direct measurements of average volume and protein, as well as on measurements of other vacuolated sulphur bacteria of similar size (Kalanetra et al., 2004).

\section{Activity assays}

The upper $1-2 \mathrm{~cm}$ of sediment was removed from the box corer and placed on ice in a nitrogen-filled glove bag (Sigma-Aldrich, Zwijndrecht, The Netherlands). For each bottle, 100 to 200 Thioploca bundles were picked from the sediment. The bundles were washed twice in the incubation medium before anaerobic transfer to $6.1 \mathrm{ml}$ vials equipped with rubber septa (Exetainer; Labco, High Wycombe, United Kingdom), or $30 \mathrm{ml}$ rubber-stoppered bottles filled with anaerobic medium. The incubation medium was made from seawater, which was made anoxic by bubbling with nitrogen and supplied with $1 \mathrm{mg} \mathrm{ml}^{-1}$ catalase. Subsequently, substrates were injected through the rubber septum under anoxic conditions. Bottles were incubated at $12{ }^{\circ} \mathrm{C}$ and the medium was changed twice during 
incubation by decanting under a nitrogen atmosphere. At specific time intervals, samples were taken and analysed for ammonium, nitrite, sulphide, thiosulphate and phosphate. Ammonium was determined colorimetrically according to Grasshoff et al. (1999). Dissolved sulphide was determined spectrophotometrically at $670 \mathrm{~nm}$ on Zn-preserved pore water by the methylene blue method (Cline, 1969). The concentration of phosphate was determined with the molybdenum blue method as described by Murphy and Riley (1962). Protein content of batches of Thioploca bundles was assayed by the microbiuret method, which is insensitive to sulphide and elemental sulphur (Otte et al., 1999). For control experiments, Thioploca bundles were disintegrated mechanically by a Potter-Elvehjem homogenizer (Fisher Scientific, Zoetermeer, The Netherlands). This treatment disrupts Thioploca cells but leaves bacteria attached to the sheath intact (Otte et al., 1999). The control was necessary to check for activity of epibiontic bacteria observed by fluorescence microscopy (A Teske, personal communication) and autoradiography (Otte et al., 1999).

For the detection of polyphosphate inclusions under the light microscope, intact Thioploca trichomes were randomly collected from Stations 7 and 18 and immersed for $30-60 \mathrm{~s}$ in a solution containing $0.3 \%$ toluidine blue in $0.5 \%$ acetic acid, then washed and inspected under the light microscope in $0.5 \%$ acetic acid (Schulz and Schulz, 2005).

\section{Quantitative microautoradiography}

Incubations for microautoradiography (MAR) were carried out on Thioploca bundles incubated in serum bottles. Individual Thioploca bundles were collected anaerobically in the same way as bundles used in physiological assays, and five bundles were placed in each $9 \mathrm{ml}$ serum bottle containing $2 \mathrm{ml}$ anaerobic pore water. The bundles were preincubated anaerobically for $0.5 \mathrm{~h}$ to remove all traces of oxygen.

Experiments were started by adding $20 \mu \mathrm{Ci}$ of ${ }^{14} \mathrm{C}$-bicarbonate and unlabelled bicarbonate to a final concentration of $100 \mu \mathrm{M}$. Combinations of phosphate $(50 \mu \mathrm{M})$, sulphide $(50 \mu \mathrm{M})$, nitrate $(50 \mu \mathrm{M})$, nitrite $(10 \mu \mathrm{M})$, oxygen $(10 \%)$ and organic substrates $(100 \mu \mathrm{M})$ were added anaerobically to individual bottles (see Table 1).

Incubations with $20 \mu \mathrm{Ci}{ }^{33} \mathrm{PO}_{4}^{3-}$ for detection of phosphate accumulation were prepared as described for bicarbonate and acetate, except for the addition of $10 \mu \mathrm{M} \mathrm{PO}{ }_{4}^{3-}, 100 \mu \mathrm{M}$ bicarbonate and combinations of sulphide $(50 \mu \mathrm{M})$, nitrate $(50 \mu \mathrm{M})$, oxygen $(10 \%)$ and organic substrates $(100 \mu \mathrm{M})$. Bottles were incubated at in situ temperature in the dark for 4 or $16 \mathrm{~h}$. Incubations were stopped by adding paraformaldehyde to a final concentration of $4 \%$. All microautoradiographic procedures were carried out as described by Nielsen and Nielsen
Table 1 Carbon fixation by Thioploca with various substrates available.

\begin{tabular}{|c|c|c|c|c|c|c|c|}
\hline \multirow[t]{2}{*}{ Organic $C$} & \multicolumn{5}{|c|}{ Substrates } & \multicolumn{2}{|c|}{ MAR index } \\
\hline & $\mathrm{PO}_{4}^{3-}$ & $\mathrm{H}_{2} \mathrm{~S}$ & $\mathrm{NO}_{3}^{-}$ & $\mathrm{NO}_{2}^{-}$ & $\mathrm{O}_{2}$ & $4 h$ & $16 \mathrm{~h}$ \\
\hline Acetate & + & + & + & & & 100 & 100 \\
\hline Propionate & + & + & + & & & 91 & 92 \\
\hline None & & + & + & & & 59 & 65 \\
\hline None & + & + & + & & & 63 & 59 \\
\hline None & + & & + & & & 63 & 55 \\
\hline None & + & + & & + & & 61 & 52 \\
\hline None & + & + & & & + & 37 & 29 \\
\hline None & + & + & & & & 18 & 26 \\
\hline
\end{tabular}

Microautoradiography index is normalized to the incubation showing the highest activity.

(2005). Length of exposure was optimized to avoid saturation of silver grains in any of the incubations. Quantification of silver grain density on Thioploca cells was done by image analysis, using the Image J software (Papadopulos et al., 2007).

\section{${ }^{15} \mathrm{~N}$-stable isotope experiments}

Unlabelled $\left({ }^{14} \mathrm{~N}\right)$ and ${ }^{15} \mathrm{~N}$-labelled ammonium, nitrite and nitrate were used to assay denitrification and anammox associated with Thioploca. Whole Thioploca bundles, disrupted Thioploca bundles or sediment surrounding Thioploca bundles were transferred to separate airtight $6.1 \mathrm{ml}$ vials equipped with rubber septa (Exetainer; Labco) under anaerobic conditions. The vials were filled with anaerobic medium (see above) leaving no headspace, and left overnight at $12{ }^{\circ} \mathrm{C}$ for temperature equilibration and consumption of residual nitrate, nitrite and ammonium. Labelled and unlabelled ammonium, nitrite, nitrate and sulphide were added in concentrations of $50-100 \mu \mathrm{M}$ at the start of the experiments, after which the samples were incubated for $24 \mathrm{~h}$ at $12^{\circ} \mathrm{C}$. Then, $1 \mathrm{ml}$ of medium was replaced with $1 \mathrm{ml}$ of argon at atmospheric pressure and the reaction was stopped with $50 \mu \mathrm{l}$ of saturated $\mathrm{ZnCl}_{2}$. The samples were stored upside down to minimize the amount of gas exchange through the septum. In some samples, the $1 \mathrm{ml}$ of removed medium was pasteurized for $15 \mathrm{~min}$ at $70^{\circ} \mathrm{C}$, and used for nitrate and nitrite analysis. After arrival in Denmark, samples were analysed in a Tracermass stable isotope ratio mass spectrometer with triple collector.

\section{Observations on trichome movements}

To examine the behaviour of individual trichomes in relation to the common sheaths, a $1.8 \mathrm{~cm}$ bundle was placed in a Petri dish with oxic seawater and cut into six pieces of different length with initially no trichomes extending out. The movement of the trichomes was subsequently monitored by photography (Ricoh Caplio RR30). 


\section{Results}

Microprofiling

Oxygen microgradients above Thioploca bundles, placed in the groove, showed that Thioploca took up oxygen. The oxygen uptake by individual Thioploca bundles with diameters of $0.4-0.5 \mathrm{~mm}$ varied from 0.3 to $1.8 \mathrm{nmol} \mathrm{cm}{ }^{-1} \mathrm{~h}^{-1}$, that is, per $\mathrm{cm}$ of bundle length. Knowing the diameter of the individual trichome bundles and assuming complete packing, this corresponds to a biovolume-specific uptake rate of 210$1040 \mu \mathrm{mol} \mathrm{dm}{ }^{-3} \mathrm{~h}^{-1}$ (corresponding to $0.5-2.5 \mathrm{nmol}$ $\mathrm{min}^{-1}$ per mg protein). Six different locations along a $3 \mathrm{~cm}$ long bundle showed an average oxygen uptake of $340 \pm 90 \mu \mathrm{mol} \mathrm{dm}^{-3} \mathrm{~h}^{-1}$ (mean \pm s.d.) when incubated with low oxygen $(\sim 30 \mu \mathrm{M})$ in the agar above the incubation groove (data not shown). The inside of the bundle remained anoxic at low ambient oxygen concentrations, but at oxygen concentrations of $100 \mu \mathrm{M}$, the inside of the bundle became oxic and a maximum oxygen uptake of $1760 \mu \mathrm{mol} \mathrm{dm}{ }^{-3} \mathrm{~h}^{-1}$ was measured (Figure 2a), which is equivalent to $4.4 \mathrm{nmol} \mathrm{min}{ }^{-1}$ per mg protein. Eight hours later, the Thioploca trichomes exposed to $100 \mu \mathrm{M}$ oxygen were dead. The oxygen uptake measured in these experiments was not due to contaminants on the sheath, because no oxygen uptake could be detected above empty sheath material and because biovolume-specific respiration rates were similar above intact bundles and trichomes protruding from the sheath.

Sulphide microgradients were measured above Thioploca bundles placed on the chamber bottom, and half-cylindrical diffusion geometry around the bundle was used to calculate sulphide uptake rates. Thioploca achieved internal zero sulphide concentrations when incubated on the flat chamber bottom in anoxic $100 \mu \mathrm{M}$ sulphide agar and, thus, the uptake was diffusion limited (Figure 2b). When the sulphide concentration in the bulk agar was raised to $200 \mu \mathrm{M}$, the inside of the Thioploca bundle became sulphidic and maximum uptake rates were calculated $\left(6220 \pm 2230 \mu \mathrm{mol} \mathrm{dm}{ }^{-3} \mathrm{~h}^{-1}\right.$, average \pm s.e.m.; Figure 2c) equivalent to $15 \pm 5.3 \mathrm{nmol} \mathrm{m^{-1 }}$ per $\mathrm{mg}$ protein. Knowing the biovolume-specific uptake, the minimum sulphide concentration at the bundle surface, which saturates this uptake, can be calculated using a cylindrical diffusion model with mass consumption.

$$
C_{\mathrm{b}}=\frac{1}{4} * \frac{u}{D} * b^{2}
$$

Where $C_{\mathrm{b}}$ is the concentration at the bundle surface, $u$ is the uptake rate, $D$ is the diffusion coefficient and $b$ is the bundle radius (derived from StenKnudsen, 2002). Hence, a bundle with a diameter of $200 \mu \mathrm{m}$ would need a sulphide concentration of $3.9 \mu \mathrm{M}$ at the surface to reach the maximum sulphide uptake. Measurements with $\mathrm{pH}$ microsensors during the sulphide uptake experiment showed no $\mathrm{pH}$ gradients $(<0.05 \mathrm{pH}$ unit) around the Thioploca bundles, due to the buffer in the medium.
No nitrous oxide microgradients were detectable above Thioploca bundles placed in the groove with acetylene and nitrate. Given the sensor detection limit of $1 \mu \mathrm{M}$ nitrous oxide, this means that denitrification rates were below $8 \mu \mathrm{mol} \mathrm{dm}^{-3} \mathrm{~h}^{-1}$

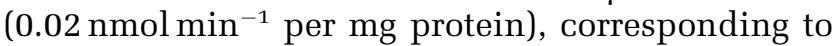
only about $0.2 \%$ of the sulphide uptake rates. Denitrification by Thioploca or associated bacteria was therefore insignificant, if present at all.

\section{Activity assays and microautoradiography}

Thioploca protein content was $310 \pm 56 \mu \mathrm{g}(n=10)$ per 100 bundles. The ammonium production rates and nitrate consumption rates measured in activity
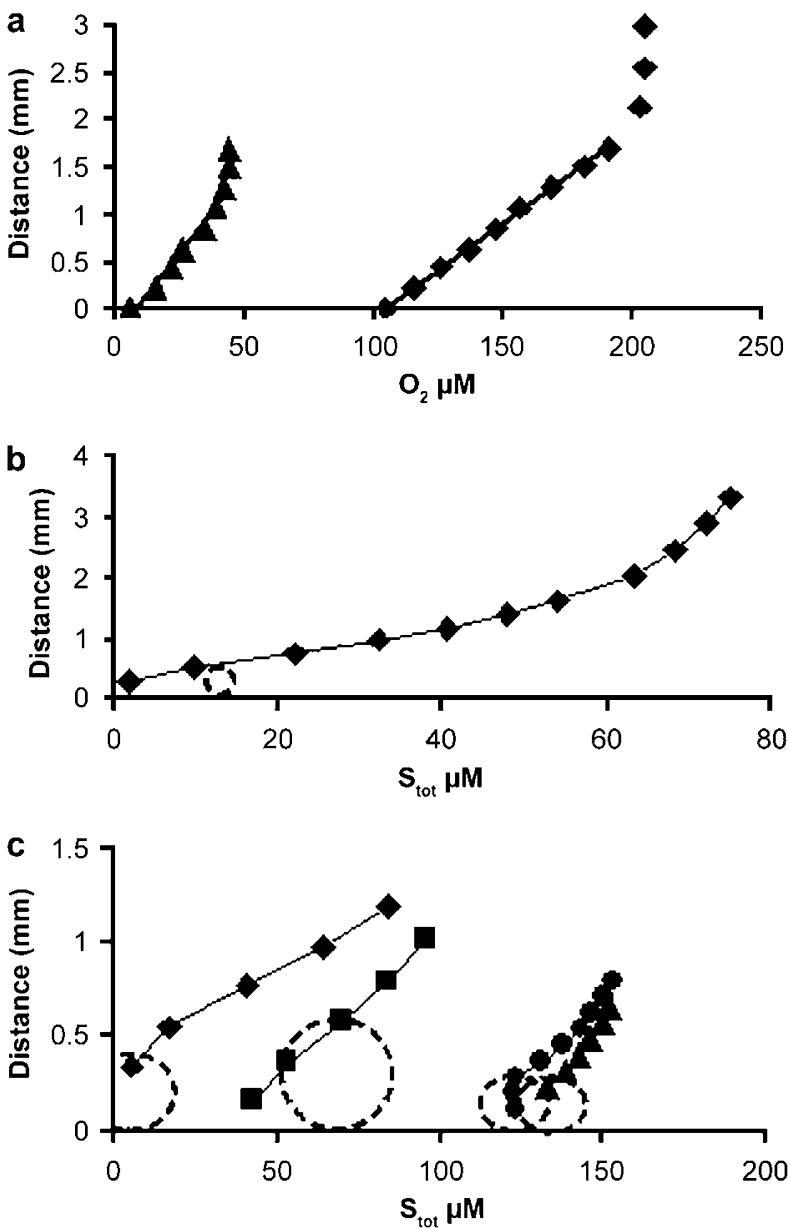

Figure 2 (a) Oxygen profiles above a Thioploca bundle (diameter $0.34 \mathrm{~mm}$ ) that had been incubated in the groove for $15 \mathrm{~min}(\boldsymbol{\Lambda})$ and for $5 \frac{1}{2} \mathrm{~h}(\bullet)$. The position of the sheath periphery is defined as zero depth. (b) Sulphide concentrations around a $0.5 \mathrm{~mm}$ Thioploca bundle placed on the surface of a glass container. Depth zero is defined by the glass surface. The position of the bundle periphery is illustrated with a broken line. (c) Sulphide gradients around bundles incubated with $200 \mu \mathrm{M}$ sulphide in the bulk agar. Diameters and biovolume-specific respiration rates of the four bundles: $\diamond, \quad 0.37 \mathrm{~mm}, \quad 12630 \mu \mathrm{mol} \mathrm{dm}^{-3} \mathrm{~h}^{-1} ; \quad \mathbf{\square}, 0.55 \mathrm{~mm}$, $2890 \mu \mathrm{mol} \mathrm{dm}^{-3} \mathrm{~h}^{-1} ; \quad \bullet \quad 0.28 \mathrm{~mm}, 5820 \mu \mathrm{mol} \mathrm{dm} \mathrm{dm}^{-3} \mathrm{~h}^{-1}$ and $\boldsymbol{\Lambda}$, $0.32 \mathrm{~mm}, 3570 \mu \mathrm{mol} \mathrm{dm} \mathrm{dm}^{-3} \mathrm{~h}^{-1}$. Depth zero is defined by the glass surface, the position of the bundle periphery is illustrated with a broken line. No pH gradient could be detected around the bundles in this buffered medium. 
assays were $1-2 \mathrm{nmol}$ per mg protein per min and 5-6.5 nmol mg protein per min, respectively. After $25 \mathrm{~h}$ of incubation some Thioploca cells started to lyse irrespective of incubation conditions.

No uptake of phosphate could be detected in three independent activity experiments where Thioploca bundles were incubated with 50-100 $\mu \mathrm{M}$ phosphate, with or without sulphide and/or with or without nitrate over a period of $24 \mathrm{~h}$. Two additional activity experiments showed that release of phosphate could not be induced by adding acetate in concentrations of 50-100 $\mu \mathrm{M}$ at different time intervals. Intracellular polyphosphate granules were not observed microscopically on staining with toluidine blue, and MAR incubations with ${ }^{33} \mathrm{PO}_{4}^{3-}$ did not show phosphate uptake (results not shown).

Results from ${ }^{14} \mathrm{C}$-bicarbonate incubations and MAR are presented in Table 1 . The number of silver grains per bacterial area was calculated by dividing the counted number of silver grains by the length of the trichome. Variation between bacterial cells in the same trichome was $<5 \%$ whereas variation between trichomes from different bundles was up to $50 \%$. Counts per area were averaged for each incubation and scaled relative to the incubation showing the highest density of silver grains, set to 100. This resulted in a MAR index, from which it is possible to compare carbon fixation between different incubations. Phosphate addition did not affect carbon fixation, neither did the presence of oxygen or sulphide. Addition of nitrate and nitrite enhanced ${ }^{14} \mathrm{CO}_{2}$ fixation by $100 \%$ to $250 \%$, and presence of organic substrates also caused increased $\mathrm{CO}_{2}$ fixation, indicating potential for mixotrophy, which supports earlier findings of Maier and Gallardo (1984b). The same trends were observed in bottles incubated for four hours and in bottles incubated for $16 \mathrm{~h}$.

\section{${ }^{15} \mathrm{~N}$-stable isotope experiments}

Intact Thioploca, disrupted Thioploca or sediment surrounding Thioploca were incubated with ${ }^{15} \mathrm{~N}$ labelled $\mathrm{NH}_{4}^{+}$together with unlabelled $\mathrm{NO}_{2}^{-}$or $\mathrm{NO}_{3}^{-}$ to detect potential anammox activity associated with Thioploca. ${ }^{29} \mathrm{~N}_{2}$ was produced in concentrations of 0.05 to $0.4 \mu \mathrm{M}$ in incubations with intact Thioploca. This corresponds to a low but significant anammox activity of 0.007 to $0.06 \mathrm{nmol} \mathrm{N}$ per min per $\mathrm{mg}$ protein. This activity was similar to incubations with disrupted Thioploca and to incubations with sediment surrounding the Thioploca (Figure 3). Therefore, the intact Thioploca did not contribute to the observed anammox activity. Addition of ${ }^{15} \mathrm{~N}$-labelled $\mathrm{NO}_{2}^{-}$or $\mathrm{NO}_{3}^{-}$to sediment surrounding Thioploca cells resulted mainly in the accumulation of $10 \mu \mathrm{M}{ }^{30} \mathrm{~N}_{2}$, which is at least two orders of magnitude higher than the observed anammox activity. A small production of ${ }^{30} \mathrm{~N}_{2}$ was detectable in the cleaned Thioploca preparations and also in control incubations with disrupted Thioploca. This

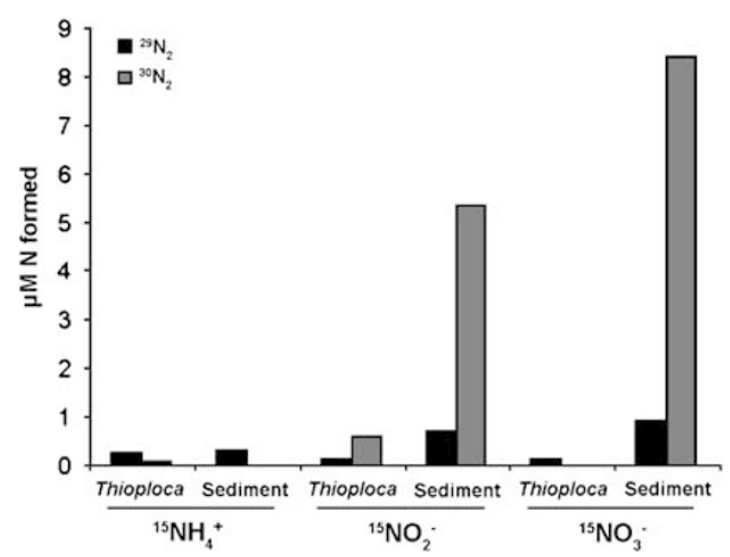

Figure $3{ }^{15} \mathrm{~N}$ labelled nitrogen gas formation after $24 \mathrm{~h}$ of incubation with ${ }^{15} \mathrm{~N}$ labelled ammonium, nitrite or nitrate, respectively. ${ }^{29} \mathrm{~N}_{2}$ formation in incubations with labelled ammonium and unlabelled nitrite or nitrate is an indication for anammox activity. ${ }^{30} \mathrm{~N}_{2}$ formation in incubations with labelled nitrate and nitrite (with unlabelled ammonium present in the sediment) is an indication for denitrification. Incubations were made in duplicates except for Thioploca incubated with ${ }^{15} \mathrm{NH}_{4}^{+}$ $(n=11)$ and sediment incubated with ${ }^{15} \mathrm{NO}_{3}^{-}(n=1)$.
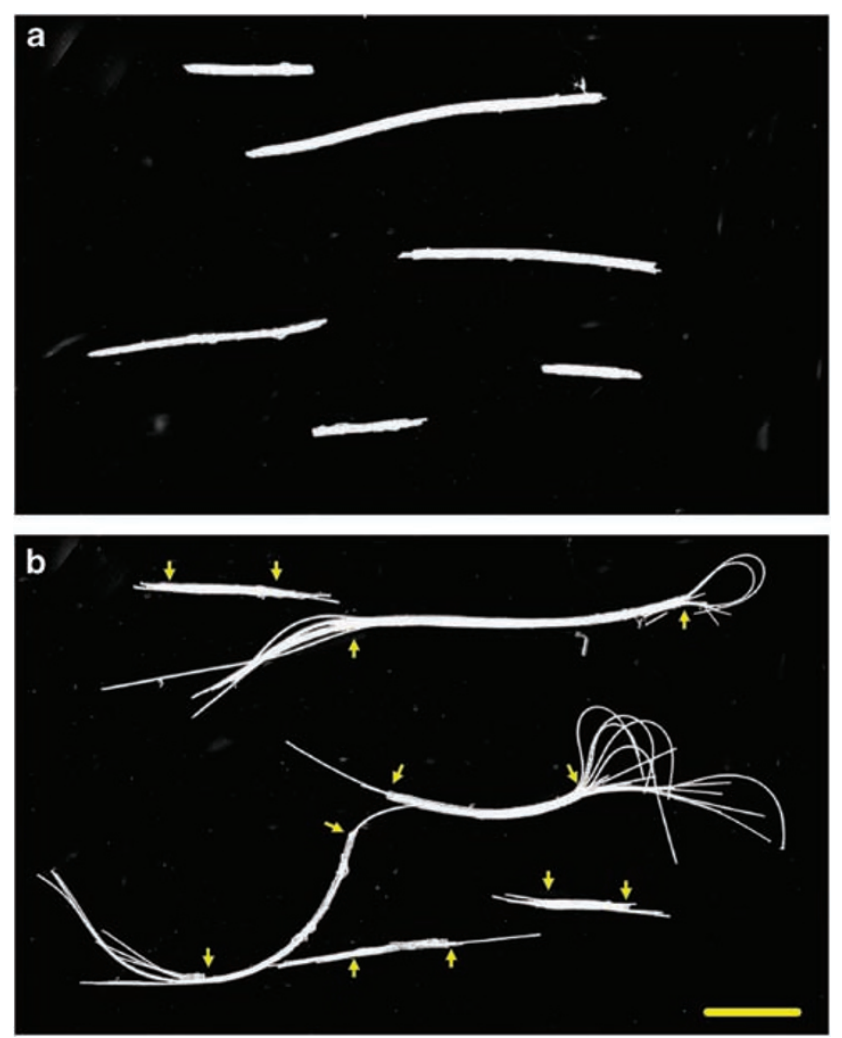

Figure 4 Bundle of Thioploca photographed just after being cut into six pieces (a) and $1 \mathrm{~h}$ later (b). The arrows indicate the limits of the slime sheaths from where the trichomes have moved out. Scale equals $0.2 \mathrm{~cm}$.

${ }^{30} \mathrm{~N}_{2}$ could have been produced by contaminating bacteria.

Behavioural observations

Thioploca bundles were divided in pieces (Figure 4a) and placed in oxic seawater. The 
individual trichome fragments instantly started to move out of the sheaths and after about $1 \mathrm{~h}$, numerous trichomes had migrated almost completely out (Figure 4b). Interestingly, no trichomes completely abandoned the sheath although they all kept moving back and forth at the same speed. Trichomes had a known maximum length corresponding to the length of the sheath piece, which they occupied. If trichomes from the short pieces had moved as long a net distance as trichomes from the long pieces, most of them would have been free of the slime sheath after one hour, but this did not happen.

\section{Discussion}

Oxygen, nitrate, sulphide and phosphorus metabolism Here we showed that Thioploca has an aerobic metabolism with a maximum oxygen uptake rate of $1760 \mu \mathrm{mol} \mathrm{dm}{ }^{-3} \mathrm{~h}^{-1}$. The maximum uptake rate is similar to the oxygen uptake by Thiomargarita (Schulz and de Beer, 2002), but contrary to Thiomargarita, Thioploca did not sustain this oxygen uptake under high oxygen concentrations for longer periods. This indicates that Thioploca is microaerophilic as suggested in motility studies by Maier and Gallardo (1984a) whereas Thiomargarita is a facultative aerobe. It is well documented that Beggiatoa is microaerophilic (Jørgensen and Revsbech, 1983; Møller et al., 1985; Nelson et al., 1986a), but there are few direct measurements of biovolume-specific oxygen uptake. Oxygen uptake rates measured on marine Beggiatoa (trichome diameter $20 \mu \mathrm{m}$ ) in a setup similar to the one of this study showed a 10 times higher biovolume-specific oxygen consumption $\left(32000 \mu \mathrm{mol} \mathrm{dm}{ }^{-3} \mathrm{~h}^{-1}\right.$, LP Nielsen et al., 2006 (unpublished data)). Thus, it seems that Thioploca and Thiomargarita, which populate OMZs and which rarely experience oxygenated conditions, have a metabolic potential less optimized for the use of oxygen than large marine Beggiatoa, which thrive in sediments underlying oxygenated bottom water (for example, Mussman et al., 2003; Preisler et al., 2007; de Beer et al., 2006).

Denitrification by Thioploca was not detectable, either by microelectrodes $(<0.2 \%$ of the sulphide uptake rates) or by ${ }^{15} \mathrm{~N}$ experiments. The ${ }^{15} \mathrm{~N}$-stable isotope experiments showed anammox activity associated with the surrounding sheath and sediment, but not with the Thioploca cells. Cooccurrence of anammox bacteria and Thioploca may explain earlier reports on formation of $\mathrm{N}_{2}$ with lower ${ }^{15} \mathrm{~N}$ labelling percentage than expected from the added ${ }^{15} \mathrm{~N}$ nitrate source (Otte et al., 1999). Anammox bacteria would have produced 14-15 dinitrogen gas from the added labelled nitrate and the unlabelled ammonium produced by Thioploca. At the time of those experiments, anammox bacteria were not known to be present in marine environments, and the results were taken as an indication of minor denitrification by epibiontic denitrifiers, although denitrification by Thioploca could not completely be ruled out (Otte et al., 1999). Our present evidence shows that these large marine Thioploca only use DNRA as a dissimilatory nitrate reduction pathway. The role of nitrite reduction in the metabolism of Thioploca was confirmed by increased carbon fixation when nitrite was supplied (Table 1). Positive taxis towards nitrite has been shown by Zopfi et al. (2001).

The reduction of nitrate to ammonium rather than to dinitrogen is possibly the more optimal use of the costly nitrate reservoir. More elemental sulphur can be gathered because DNRA transfer eight electrons per nitrate molecule reduced, compared to five by denitrification. The thermodynamic energy gain by DNRA is actually similar to denitrification when expressed per mole nitrate reduced (Jørgensen and Nelson, 2004; Gray and Head, 2005) and in terms of growth yield it may be even higher (Strohm et al., 2007).

To compare the measured rates of sulphide uptake to rates of elemental sulphur oxidation by oxygen or nitrate, it is useful to convert all measured rates into moles of oxidized sulphur. The oxygen uptake was measured in a setup without external supply of sulphide or other electron donors. The consumed oxygen can, therefore, be assumed to be used primarily for the oxidation of stored sulphur:

$$
2 \mathrm{~S}_{0}+3 \mathrm{O}_{2}+2 \mathrm{H}_{2} \mathrm{O} \rightarrow 2 \mathrm{SO}_{4}^{2-}+4 \mathrm{H}^{+}
$$

According to this stoichiometry, the maximum sulphur oxidation by oxygen should be $1170 \mu \mathrm{mol}$ $\mathrm{S}$ per $\mathrm{dm}^{3}$ per h (equal to $2.9 \mathrm{nmol} \mathrm{S}$ per min per $\mathrm{mg}$ protein).

Elemental sulphur is also oxidized by nitrate.

$$
4 \mathrm{~S}_{0}+3 \mathrm{NO}_{3}^{-}+7 \mathrm{H}_{2} \mathrm{O} \rightarrow 4 \mathrm{SO}_{4}^{2-}+3 \mathrm{NH}_{4}^{+}+2 \mathrm{H}^{+}
$$

DNRA rates were $1-2 \mathrm{nmol} \mathrm{N}$ per min per mg protein when no external sulphide was present. Thus, stored sulphur was oxidized in these experiments and the DNRA rate translates to a sulphur oxidation rate of $1.3-2.6 \mathrm{nmol} \mathrm{S}$ per min per $\mathrm{mg}$ protein. Therefore, aerobic and anaerobic oxidation of stored sulphur occur at similar rates, which likely reflects the basic metabolic rate in Thioploca cells.

The measured potential sulphide uptake rate of $6220 \mu \mathrm{mol} \mathrm{S}$ per $\mathrm{dm}^{3}$ per h $(15 \mathrm{nmol} \mathrm{S}$ per min per mg protein) was 5-6 times faster than the continuous oxidation rate of stored sulphur. This rate difference shows that, during sulphide oxidation, elemental sulphur accumulates fast compared to the subsequent oxidation of stored elemental sulphur to sulphate. The presence of sulphide in the bulk medium did not induce higher carbon fixation rates in the MAR experiments (Table 1). This indicates that the rapid sulphide uptake is uncoupled from carbon fixation and energy conservation, and displays a mechanism for fast accumulation of elemental sulphur, when high concentrations of sulphide are present. 
The use of polyphosphate as a dynamic energy storage, as described for Thiomargarita (Schulz and Schulz, 2005), could not be detected in Thioploca, neither with toluidine blue staining nor with activity assays with phosphate or the more sensitive ${ }^{33} \mathrm{PO}_{4}^{3-}$ MAR incubations. For comparison, the latter method would have detected a cellular phosphate content corresponding to $0.1 \%$ of the phosphate stored by phosphate accumulating bacteria from wastewater treatment plants (Hesselsøe et al., 2005).

\section{Thioploca physiology: adaptations to ephemeral} electron donors and acceptors

Many basic physiological parameters have been quantified in this as well as in other studies (Table 2) and we now see a more complete picture of the Thioploca physiology. Thioploca is well adapted to a fluctuating environment. This can be seen in the accumulation and transport of nitrate and sulphur, which permit a metabolic strategy independent of the coexistence of electron donor and acceptor (Fossing et al., 1995), and also in the fast rate of sulphur storage.

Thioploca trichomes are usually not observed to protrude from the sheath within the sediment (BB Jørgensen, personal observation), and the uptake of sulphide occurs while the trichomes are within the sheath. From the maximum sulphide uptake rate it was calculated that an average Thioploca bundle needs a minimum of $4 \mu \mathrm{M}$ sulphide at the bundle surface to saturate the sulphide uptake. This indicates that, in the present environment, Thioplo$c a$ are adapted to long periods with no measurable dissolved sulphide $(<1 \mu \mathrm{M}$; Thamdrup and Canfield, 1996; Ferdelman et al., 1997) by holding a high capacity to exploit the occasional presence of sulphide concentrations up to $800 \mu \mathrm{M}$ (Høgslund et al., 2008; L Holmkvist et al., in preparation).

Thioploca is a slow-growing mixotrophic bacterium capable of using inorganic carbon as well as acetate and propionate for biomass production (Table 1). This observation is in accordance with previous studies (Maier and Gallardo, 1984b). In the present study MAR also showed that carbon dioxide fixation was enhanced by the presence of external electron acceptors (Table 1), and previous labelling experiments have shown that Thioploca cells readily reduce external nitrate without first storing it inside the vacuoles (Otte et al., 1999). This strategy differs from the cellular management of sulphur. We showed that high sulphide concentrations did not increase carbon fixation (Table 1) but induced rapid sulphur storage. This difference in response to

Table 2 Summation of quantitative measures of physiology and behaviour of marine Thioploca

\begin{tabular}{|c|c|c|c|}
\hline & Range & Unit & Reference \\
\hline Sulphide uptake & $0.7-15^{\mathrm{a}}$ & $\mathrm{nmol} \min ^{-1}$ per mg protein & Present study; Otte et al. (1999) \\
\hline Sulphate production & $2-3$ & $\mathrm{nmol} \min ^{-1}$ per mg protein & Otte et al. (1999) \\
\hline Oxygen consumption & $0.5^{\mathrm{a}}-4.4^{\mathrm{a}}$ & nmol $\min ^{-1}$ per mg protein & Present study \\
\hline DNRA & $1-4$ & nmol $\min ^{-1}$ per mg protein & Present study; Otte et al. (1999) \\
\hline Denitrification & $<0.02^{\mathrm{a}}$ & nmol $\min ^{-1}$ per mg protein & Present study \\
\hline Nitrate uptake & $5-6.5$ & nmol $\min ^{-1}$ per mg protein & Present study \\
\hline Internal nitrate storage & $10-500$ & $\mathrm{mM}$ & $\begin{array}{l}\text { Otte et al. (1999); } \\
\text { Fossing et al. (1995) }\end{array}$ \\
\hline Internal sulphur storage & & & Zopfi et al. (2001) \\
\hline T. chileae & $50-800$ & $\mathrm{mM}$ & \\
\hline T. araucae & $10-355$ & $\mathrm{mM}$ & \\
\hline SCM & $10-800$ & $\mathrm{mM}$ & \\
\hline Phosphate storage & None & & Present study \\
\hline Doubling time & 69-139 & days & Otte et al. (1999) \\
\hline $\mathrm{CO}_{2}$ fixation & $0.4-1.5$ & nmol $\min ^{-1}$ per mg protein & $\begin{array}{l}\text { Otte et al. (1999); } \\
\text { Ferdelman et al. (1997) }\end{array}$ \\
\hline Acetate uptake & 0.4 & nmol min $^{-1}$ per mg protein & Otte et al. (1999) \\
\hline Motility & $0.37-14.8$ & $\mathrm{~mm} \mathrm{~h}^{-1}$ & Huettel et al. (1996) \\
\hline Negative taxi & Threshold value & & \\
\hline $\begin{array}{l}\mathrm{O}_{2} \\
\mathrm{H}_{2} \mathrm{~S}\end{array}$ & $\begin{array}{c}>10 \% \text { air saturation } \\
>500 \mu \mathrm{M}\end{array}$ & & Huettel et al. (1996) \\
\hline \multicolumn{4}{|l|}{ Positive taxi } \\
\hline $\mathrm{NO}_{2}^{-}$ & $>4 \mu \mathrm{M}$ & & Zopfi et al. (2001) \\
\hline $\mathrm{NO}_{3}^{-}$ & $>25 \mu \mathrm{M}$ & & Huettel et al. (1996) \\
\hline $\mathrm{H}_{2} \mathrm{~S}$ & $<100 \mu \mathrm{M}$ & & \\
\hline Organic substrates & $\begin{array}{l}\text { Acetate, amino acids, } \\
\text { glucose, glycine, thymidine }\end{array}$ & & $\begin{array}{l}\text { Otte et al. (1999); } \\
\text { Maier and Gallardo (1984b) }\end{array}$ \\
\hline
\end{tabular}

Abbreviations: DNRA, dissimilatory nitrate reduction to ammonium; SCM, short cell morphotype.

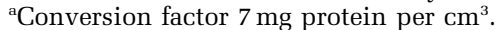


sulphide and nitrate indicates that sulphide is the limiting substrate for Thioploca.

The organization of Thioploca trichomes in large bundles enhances the diffusion limitation already imposed by the large cell size. In the case of nitrate, this problem is effectively overcome by stretching the individual trichomes out of the sheaths in the sediment and into the overlying water, thus penetrating the diffusive boundary layer (Huettel et al., 1996). Nitrate uptake can, therefore, occur efficiently even though nitrate is present in low $(\sim 10 \mu \mathrm{M})$ concentrations. In the case of sulphide uptake, trichomes remain in the sheath and are well adapted to exploit periodically high $(<200 \mu \mathrm{M})$ sulphide concentrations following massive organic matter sedimentation. The low substrate affinity of the intact bundle seems to be counterbalanced by the capacity for rapid sulphur storage. This might be their major advantage in the competition with other sulphide consuming organisms and processes in the sediment.

The Thioploca may benefit from the sheath in sediments that lack a sulphide gradient to guide trichome movement. Previous studies show that the largely vertical orientated sheaths allow a more directional and, therefore, much more rapid return from the sediment to the nitrate source, than would be possible if the trichomes were moving in a 'random walk' fashion (Schulz et al., 1996). The closely related Beggiatoa, which do not have a sheath to give direction, seem to require a sulphide gradient to make the trichomes return from the subsurface sediment to the surface (Preisler et al., 2007).

The behaviour of Thioploca is optimized for the periodic availability and spatial separation of electron donor and acceptor. Previous studies have shown that Thioploca trichomes have a positive taxis towards nitrate, which has priority over a phobic response to oxygen when nitrate and oxygen are present in the bottom water (Huettel et al., 1996). Interestingly, protruding trichomes reverse the direction of movement just in time to avoid leaving their common sheath (Figure 4). However, the mechanisms that allow the trichomes not to lose contact with the sheath remain to be resolved. Low sulphide concentrations cause a fast positive chemotactic response by Thioploca trichomes, but Thioploca shows phobic reaction to high sulphide concentrations (Huettel et al., 1996). The return of trichomes from the deep sediment to the surface is not triggered by low vacuolar nitrate concentrations (Zopfi et al., 2001) and it is still unclear whether depletion or saturation of nitrate and sulphur storage control their behaviour.

\section{Acknowledgements}

We thank all participants on the 2006 Thioploca-Chile Expedition for their scientific support. We also thank the staff of Dichato Marine Biological Station and the crew of R/V Kay Kay of the University of Concepción for their help and hospitality. This work was supported by the Max Planck Society and the Danish Natural Science Research Council Grants 21-03-0500 and 272-06-0504 and the Department of Oceanography of the University of Concepción, Census of Marine Life Program, and FONDECYT Project no. 1070552 to VAG.

\section{References}

Ahmad A, Kalanetra KM, Nelson DC. (2006). Cultivated Beggiatoa spp. define the phylogenetic root of morphologically diverse, noncultured, vacuolate sulfur bacteria. Can J Microbiol 52: 591-598.

Andersen K, Kjær T, Revsbech NP. (2001). An oxygen insensitive microsensor for nitrous oxide. Sens Actuators B Chem 81: 42-48.

Arning ET, Birgel D, Schulz-Vogt HN, Holmkvist L, Jørgensen BB, Larson A et al. (2008). Lipid biomarker patterns of phosphogenic sediments from upwelling regions. Geomicrobiol J 25: 69-82.

Bernhard JM, Buck KR. (2004). Eukaryotes of soledad, cariaco and santa barbara basins: protists and metazoans associated with deep-water marine sulfidoxidizing microbial mats and their possible effects on the geologic record. In: Amend JP, Edwards KJ, Lyons TW (eds). Sulfur Biogeochemistry-Past and Present, vol. 379, Special paper GSA. Geological Society of America: Boulder, CO, pp 35-47.

Cline JD. (1969). Spectrophotometric determination of hydrogen sulfide in natural waters. Limnol Oceanogr 14: $454-458$.

Crank J. (1983). The mathematics of diffusion. Oxford University Press, London.

de Beer D, Sauter E, Niemann H, Kaul N, Foucher JP, Witte $\mathrm{U}$ et al. (2006). In situ fluxes and zonation of microbial activity in surface sediments of the Hakon Mosby Mud Volcano. Limnol Oceanogr 51: 1315-1331.

Ferdelman TG, Lee C, Pantoja S, Harder J, Bebout BM, Fossing H. (1997). Sulfate reduction and methanogenesis in a Thioploca-dominated sediment off the coast of Chile. Geochim Cosmochim Acta 61: 3065-3079.

Fossing H, Gallardo VA, Jørgensen BB, Huttel M, Nielsen LP, Schulz H et al. (1995). Concentration and transport of nitrate by the mat-forming sulfur bacterium Thioploca. Nature 374: 713-715.

Gallardo VA. (1963). Notas sobre la densidad de la fauna bentónica en el sublittoral del norte de Chile. Gayana (Zool) 10: 3-15.

Gallardo VA. (1977a). Large benthic microbial communities in sulphide biota under Peru-Chile Subsurface Cuntercurrent. Nature 268: 331-333.

Gallardo VA. (1977b). On the discovery of a large microbial community living in the soft bottoms of the continental shelf off Chile and Peru. Anales Inst Invest Marinas Pta Betín Colombia Supl 1: 23-30.

Gallardo VA, Espinoza C. (2007a). New communities of large filamentous sulfur bacteria in the eastern South Pacific. Int Microbiol 10: 97-102.

Gallardo VA, Espinoza C. (2007b). Large multicellular filamentous bacteria under the oxygen minimum zone of the eastern South Pacific: a forgotten biosphere. In: Richard BH, Gilbert VL, Alexei YR, Paul CWD 
(eds). Instruments, Methods, and Missions for Astrobiology, vol. 6694. Procof SPIE: Bellingham, USA, pp $1 \mathrm{H}-11 \mathrm{H}$.

Grasshoff K, Kremling K, Ehrhardt M. (1999). Methods of Seawater Analysis. Wiley: New York.

Gray ND, Head IM. (2005). Minerals, mats, pearls and veils: themes and variations in giant sulphur bacteria. In: Gadd GM, Semple KT, Lappin-Scott (eds). MicroOrganisms and Earth Systems. Cambridge University Press: Cambridge, pp 35-70.

Hershey JP, Plese T, Millero FJ. (1988). The Pk1-star for the dissociation of $\mathrm{H}_{2} \mathrm{~S}$ in various ionic media. Geochim Cosmochim Acta 52: 2047-2051.

Hesselsø M, Nielsen JL, Roslev P, Nielsen PH. (2005). Isotope labeling and microautoradiography of active heterotrophic bacteria on the basis of assimilation of ${ }^{14} \mathrm{CO}_{2}$. Appl Environ Microbiol 71: 646-655.

Høgslund S, Revsbech NP, Cedhagen T, Nielsen LP, Gallardo VA. (2008). Denitrification, nitrate turnover and aerobe respiration by benthic foraminifera in the oxygen minimum zone off Chile. J Exp Mar Bio Ecol 359: 85-91.

Huettel M, Forster S, Kloser S, Fossing H. (1996). Vertical migration in the sediment-dwelling sulfur bacteria Thioploca spp in overcoming diffusion limitations. Appl Environ Microbiol 62: 1863-1872.

Jørgensen BB, Nelson DC. (2004). Sulfide oxidation in marine sediments: geochemistry meets microbiology. In: Amend JP, Edwards K, Lyons TW (eds). Sulfur Biogeochemistry-Past and Present vol. 379. Special paper GSA, pp 63-81.

Jørgensen BB, Revsbech NP. (1983). Colorless sulfur bacteria, Beggiatoa spp and Thiovulum spp in $\mathrm{O}_{2}$ and $\mathrm{H}_{2} \mathrm{~S}$ microgradients. Appl Environ Microbiol 45: 1261-1270.

Jørgensen BB, Teske A, Ahmad A. (2005). Thioploca. In: Krieg NR, Staley JT, Brenner DJ (eds). Bergey's Manual of Systematic Bacteriology, vol. 2. pp 171-178.

Kalanetra KM, Huston SL, Nelson DC. (2004). Novel, attached, sulfur-oxidizing bacteria at shallow hydrothermal vents possess vacuoles not involved in respiratory nitrate accumulation. Appl Environ Microbiol 70: 7487-7496.

Kuhl M, Steuckart C, Eickert G, Jeroschewski P. (1998). A $\mathrm{H}_{2} \mathrm{~S}$ microsensor for profiling biofilms and sediments: application in an acidic lake sediment. Aquat Microb Ecol 15: 201-209.

Maier S, Gallardo VA. (1984a). Thioploca araucae sp. nov. and Thioploca chileae sp. nov. Int J Syst Microbiol 34: 414-418.

Maier S, Gallardo VA. (1984b). Nutritional characteristics of two marine Thioplocas determined by autoradiography. Arch Microbiol 139: 218-220.

McHatton SC, Barry JP, Jannasch HW, Nelson DC. (1996). High nitrate concentrations in vacuolate, autotrophic marine Beggiatoa spp. Appl Environ Microbiol 62: 954-958.

Møller MM, Nielsen LP, Jørgensen BB. (1985). Oxygen responses and mat formation by Beggiatoa spp. Appl Environ Microbiol 50: 373-382.

Murphy J, Riley JP. (1962). A modified single solution method for determination of phosphate in natural waters. Anal Chem Acta 26: 31-35.

Mussmann M, Hu FZ, Richter M, de Beer D, Preisler A, Jørgensen BB et al. (2007). Insights into the genome of large sulfur bacteria revealed by analysis of single filaments. PLoS Biol 5: 1923-1937.
Mussmann M, Schulz HN, Strotmann B, Kjær T, Nielsen LP, Rossello-Mora RA et al. (2003). Phylogeny and distribution of nitrate-storing Beggiatoa spp. in coastal marine sediments. Environ Microbiol 5: $523-533$.

Nelson DC, Jørgensen BB, Revsbech NP. (1986a). Growthpattern and yield of a chemoautotrophic Beggiatoa sp in oxygen-sulfide microgradients. Appl Environ Microbiol 52: 225-233.

Nelson DC, Revsbech NP, Jørgensen BB. (1986b). Microoxic-anoxic niche of Beggiatoa spp-Microelectrode survey of marine and fresh-water strains. Appl Environ Microbiol 52: 161-168.

Nielsen JL, Nielsen PH. (2005). Advances in microscopy: microautoradiography of single cells. Methods Enzymol 397: 237-246.

Otte S, Kuenen JG, Nielsen LP, Paerl HW, Zopfi J, Schulz HN et al. (1999). Nitrogen, carbon, and sulfur metabolism in natural Thioploca samples. Appl Environ Microbiol 65: 3148-3157.

Papadopulos F, Spinelli M, Valente S, Foroni L, Orrico C, Alviano $\mathrm{F}$ et al. (2007). Common tasks in microscopic and ultrastructural image analysis using ImageJ. Ultrastruct Pathol 31: 401-407.

Preisler A, de Beer D, Lichtschlag A, Lavik G, Boetius A, Jørgensen BB. (2007). Biological and chemical sulfide oxidation in a Beggiatoa inhabited marine sediment. ISME J 1: 341-353.

Prokopenko MG, Hammond DE, Berelson WM, Bernhard JM, Stott L, Douglas R. (2006). Nitrogen cycling in the sediments of Santa Barbara basin and Eastern Subtropical North Pacific: nitrogen isotopes, diagenesis and possible chemosymbiosis between two lithotrophs (Thioploca and Anammox)-"riding on a glider”. Earth Planet Sci Lett 242: 186-204.

Revsbech NP. (1989). An oxygen microsensor with a guard cathode. Limnol Oceanogr 34: 474-478.

Revsbech NP, Jørgensen BB. (1986). Microelectrodestheir use in microbial ecology. Adv Microb Ecol 9: 293-352.

Sayama M. (2001). Presence of nitrate-accumulating sulfur bacteria and their influence on nitrogen cycling in a shallow coastal marine sediment. Appl Environ Microbiol 67: 3481-3487.

Sayama M, Risgaard-Petersen N, Nielsen LP, Fossing H, Christensen PB. (2005). Impact of bacterial $\mathrm{NO}_{3}^{-}$ transport on sediment biogeochemistry. Appl Environ Microbiol 71: 7575-7577.

Schmaljohann R, Drews M, Walter S, Linke P, von Rad U, Imhoff JF. (2001). Oxygen-minimum zone sediments in the northeastern Arabian Sea off Pakistan: a habitat for the bacterium Thioploca. Mar Ecol Prog Ser 220: 295-295.

Schulz HN, Brinkhoff T, Ferdelman TG, Marine MH, Teske A. (1999). Dense populations of a gigant sulfur bacterium in Namibian shelf sediments. Science 284: 493-495.

Schulz HN, de Beer D. (2002). Uptake rates of oxygen and sulfide measured with individual Thiomargarita namibiensis cells by using microelectrodes. Appl Environ Microbiol 68: 5746-5749.

Schulz HN, Jørgensen BB. (2001). Big bacteria. Annu Rev Microbiol 55: 105-137.

Schulz HN, Jørgensen BB, Fossing HA, Ramsing NB. (1996). Community structure of filamentous, sheathbuilding sulfur bacteria, Thioploca spp, off the coast of Chile. Appl Environ Microbiol 62: 1855-1862. 
Schulz HN, Schulz HD. (2005). Large sulfur bacteria and the formation of phosphorite. Science 307: 416-418.

Schulz HN, Strotmann B, Gallardo VA, Jørgensen BB. (2000). Population study of the filamentous sulfur bacteria Thioploca spp. off the Bay of Concepcion, Chile. Mar Ecol Prog Ser 200: 117-126.

Smith MS, Firestone MK, Tiedje JM. (1978). Acetylene inhibition method for short-term measurement of soil denitrification and its evaluation using N-13. Soil Sci Soc Am J 42: 611-615.

Sten-Knudsen O. (2002). Biological Membranes, Theory of Transport, Potentials and Electrical impulsesa. Cambridge University press: Cambridge.

Strohm TJ, Griffin B, Zumft WG, Schink B. (2007). Growth yields in bacterial denitrification and nitrate ammonification. Appl Environ Microbiol 73: 1420-1424.
Sweerts J, Debeer D, Nielsen LP, Verdouw H, Vandenheuvel JC, Cohen Y et al. (1990). Denitrification by sulfur oxidizing Beggiatoa Spp. mats on fresh-water sediments. Nature 344: 762-763.

Teske A, Ramsing NB, Kuver J, Fossing H. (1996). Phylogeny of Thioploca and related filamentous sulfide-oxidizing bacteria. Syst Appl Microbiol 18: $517-526$

Thamdrup B, Canfield DE. (1996). Pathways of carbon oxidation in continental margin sediments off central Chile. Limnol Oceanogr 41: 1629-1650.

Zopfi J, Kjær T, Nielsen LP, Jørgensen BB. (2001). Ecology of Thioploca spp.: nitrate and sulfur storage in relation to chemical microgradients and influence of Thioploca spp. on the sedimentary nitrogen cycle. Appl Environ Microbiol 67: 5530-5537. 